\title{
Assessment and selection based on girth and yield performance of new Hevea genotypes generated from controlled hybridization
}

\author{
P V A Anushka*, S P Withanage**, N P S N Karunaratne**, \\ K V V S Kudaligama**, T T D Dahanayake** and H P Peiris** \\ * 25/A, Capron Street, Crawley, WA 6009, Australia \\ ** Rubber Research Institute of Sri Lanka, Dartonfield, Agalawatta, Sri Lanka
}

\begin{abstract}
The objective of this study was to evaluate the girth and yield performance of new Hevea genotypes obtained from the 1998 hand pollination (HP) program. Sixty-five new genotypes were assessed along with the control clones viz. RRIC 121, RRIC 130 and RRISL 205. Dry rubber yield for six years, annual girth at the $14^{\text {th }}$ year and girth increment, percentage of tappable trees, survival trees and tapping panel dryness affected trees and latex properties of selected genotypes were evaluated. Considering the results, $63 \%$ of the genotypes were recorded as significantly higher or similar average yield compared to control clones. The genotypes, 98-80 and 98-219 were the top-rankers with average yields of $53.7 \mathrm{~g}$ and $52.0 \mathrm{~g}$ per tree per tapping, respectively. Moreover, the progeny generated from 1998 hand pollination consisted of good yielders similar to the yield of the clone RRIC 121 and could be considered as potential candidates for future clonal selection programmes to develop elite clones. Eighty-two percent of the genotypes showed significantly higher or similar mean girth compared to controls. Genotypes, 98-276 and 98-68 were ranked at number one and two, which have obtained respective girth values of $80.6 \mathrm{~cm}$ and $76.5 \mathrm{~cm}$. Eighteen percent of genotypes recorded more than $70 \mathrm{~cm}$ of mean girth, which was an indicator of the development of vigorous timber clones in the future. Moreover, these genotypes possess high yield potential. Almost all the genotypes had significantly high girth increment during the immature phase than the post tapping phase. Genotypes 98-80 and 98-219 had performed well based on the dry rubber content (DRC), sucrose and inorganic phosphorus values. In conclusion, the 1998 HP programmes has generated a valuable pool of genotypes that have paved the path to producing outstanding Hevea clones.
\end{abstract}

Key words: controlled hybridization, genotypes, girth, Hevea brasiliensis, tapping panel dryness, yield

\section{Introduction}

Almost all the popular clones available in major rubber growing countries are entirely developed through conventional breeding procedures (Reju et al., 2016) and the hybridization is a major conventional breeding procedure in rubber breeding other than introduction 
P V A Anushka et al.

and selection (Goncalves et al., 2007 \& 2011). The breeding procedure is mainly focused on developing high yielding clones. Yet, other characteristics such as vigour and disease resistance are also considered. Breeding trials related to natural rubber research in Sri Lanka is done mainly in three stages. In the first stage, a progeny obtained from the hand pollination is planted in the nursery and subjected to preliminary evaluation. The best genotypes selected from the preliminary evaluation are then established in small-scale clonal trials (SSCTs) as the second stage. For SSCTs bud grafted genotypes are used with 1520 replicates from each genotype along with recommended clones as controls. It takes approximately 10-12 years to select the best performing genotypes from SSCTs and the selected genotypes are incorporated to Estate/RRI colaborative trials (ECTs) at the third stage. It takes another 10-12 years to select outstanding genotypes from the ECTs and to include in the Group III of RRISL clone recommendation. It will take another 20-25 years to upgrade new clones into Group II and Group I respectively, from Group III. However, this procedure takes many more years to reach a clone up to Group I. Thus, currently only five clones represent group I and these clones occupy a large share in the rubber sector in Sri Lanka. Department of Genetics and Plant Breeding of RRISL involve in the annual hand pollination procedure to improve genotypes through hybridization to increase the number of clones along with the interim clone recommendation procedure to solve this problem. Under interim clone recommendation, Group II and III clones are also evaluated in smallholder level in addition to estate level, before up graded into Group I (Attanayake, 2001 and Withanage et al., 2014).

During the breeding procedure, both girth and yield parameters are widely used as attributes of growth and good harvesters. Girth is the key factor taken into consideration for evaluating growth and attainment of crop maturity for harvesting (Chandrasekhar et al., 2005). Average yield is an important factor for Hevea clonal selection (Reju et al., 2016). Therefore, at the final stage of selection, average yield per tree per tapping is considered as the main selection criterion.

This article focuses on assessing genotypes obtained from 1998 hand pollination programme based on average girth, girth increment, average yield and latex physiological properties evaluated in small-scale clone trials in selecting best performing genotypes for developing new clones for future.

\section{Materials and Methods \\ Location}

The experiment was carried out at the Department of Genetics and Plant Breeding at Kuruwita sub-station, Rubber Research Institute, Sri Lanka. Kuruwita is located in Ratnapura district experiencing a tropical climate which is favorable for rubber cultivation.

\section{Small-scale clone trial of $98 \mathrm{HP}$ progeny}

Two hundred and eighty four seedlings were generated from 1998 hand 
pollination (HP) programme by using clones PB 260 and RRIC 130 as parents. Better performing seedlings were selected after evaluating their juvenile yield (micro tapping), girth, bark thickness and other secondary attributes such as disease resistance at the three years old mother plant nursery. From these, 65 genotypes were selected and cloned through bud grafting and the plants were established in a small-scale clone trial along with RRIC 121, RRIC 130 and RRISL 205 as controls at the RRISL sub-station in Kuruwita in 2001. The small-scale clone trial was conducted as three separate trials with 22 genotypes and three control clones (25 treatments) per trial. Each trial was laid according to a completely randomized design with 16 trees per genotype/clone (per treatment). Tappability of the genotypes was determined when more than $65 \%$ of trees under each trial have reached a girth of $50 \mathrm{~cm}$ and beyond. The trees were opened for tapping at the age of eight years. The tapping system followed was $1 / 2 \mathrm{SD} 2$.

\section{Measurement of girth, yield and other growth parameters}

Dry rubber yield per tree per tapping in grams $(\mathrm{g} / \mathrm{t} / \mathrm{t})$ over six years and girth of the trees, 14 years after planting were recorded. Data on average annual yield in consequent six years were recorded after opening the panel for tapping by the cup coagulation method, in two normal tapping days per month. During the cup coagulation method $2 \%$ acetic acid solution was added to the latex of individual trees in the collecting cup and stirred. Thereafter, coagulated rubber was pressed and dried until a constant weight to record the test tapped yield. Annual girths of the trees were recorded at the height of $120 \mathrm{~cm}$ above the bud union; which was started during the second year of planting and were used to determine the girth increment. Incidences of diseases were also assessed by visual observations during the experimental period. The data on percentage of survival at the opening of tapping and the percentage of Tapping Panel Dryness (TPD) at sixth year of tapping was calculated. The data on yield and girth were statistically analyzed using Analysis of Variance (ANOVA) followed by mean separation by Duncan's Multiple Range Tests using SAS ver. 9.2.

\section{Measurement of latex physiological properties}

The selected best performing genotypes and the control clone, RRIC 121 were subjected to testing of latex physiological properties. Randomly selected latex samples (five replicates from each genotype) were collected to the vessels, immersed in ice, avoiding latex dripped for the initial five minutes after tapping and then serum was extracted by coagulating $2.5 \mathrm{~g}$ of latex in $25 \mathrm{ml}$ of $2.5 \%$ trichloro acetic acid (TCA) and used to quantify sucrose content (Scott and Melvin, 1953), inorganic phosphorus content (Taussky and Shorr, 1953), thiol content (Boyne and Ellman, 1972) and polyphenol content (Turkmen et al., 2006). By using standard ISO method (Anon., 1984), dry rubber content of latex of each sample was analyzed. 
P V A Anushka et al.

\section{Results and Discussion}

Yield performances

The values of average dry rubber yield of all the tested genotypes from three trials including control clones are given in Table 1, ranking in descending order. In the early years of tapping, yield per tree $(\mathrm{g} / \mathrm{t} / \mathrm{t})$ is a good indication of the yield potential than the yield per hectare, due to wide variations in tappability or tappable stand per hectare among clones at opening (Gonçalves et al., 2007). Mean dry rubber yield varied among genotypes and controls. Average tree yield per tapping for six years showed that yield level among genotypes varied between $52.0 \mathrm{~g}$ and $23.46 \mathrm{~g}$ in trial 1 ,
$53.7 \mathrm{~g}$ and $23.9 \mathrm{~g}$ in trial 2 and $45.1 \mathrm{~g}$ (RRIC 121) and $18.8 \mathrm{~g}$ in trial 3. Genotypes, 98-219 and 98-80 showed the highest mean dry rubber yields, which were greater than the control clone, RRIC 121. There were 33 genotypes above the yield of RRIC 130 and 38 genotypes above the yield of clone RRISL 205. Collectively, there were 40 new genotypes $(62.5 \%)$ which were superior to the control clones in this aspect. Genotype, 98-219 of the trial 1 and genotype $98-80$ of the trial 2 were the top-ranking genotypes which have given the highest mean yield of $52 \mathrm{~g} / \mathrm{t} / \mathrm{t}$ and $53.7 \mathrm{~g} / \mathrm{t} / \mathrm{t}$ (Table 1).

Table 1. Sixth year average yield $(\mathrm{g} / \mathrm{t} / \mathrm{t})$ of $1998 \mathrm{HP}$ genotypes along with control clones from Trial 1, Trial 2 and Trial 3

\begin{tabular}{lllllllll}
\hline & Trial 1 & & \multicolumn{3}{c}{ Trial 2 } & \multicolumn{3}{c}{ Trial 3 } \\
\hline Clone & $\begin{array}{l}\text { Average } \\
\text { yield }\end{array}$ & Rank & Clone & $\begin{array}{l}\text { Average } \\
\text { yield }\end{array}$ & Rank & Clone & $\begin{array}{l}\text { Average } \\
\text { yield }\end{array}$ & Rank \\
\hline $98-219$ & $52.04^{\text {a }}$ & 1 & $98-80$ & $53.66^{\text {a }}$ & 1 & RC121* & $45.14^{\text {a }}$ & 1 \\
RC121* & $51.58^{\text {ab }}$ & 2 & RC121* & $43.66^{\text {ab }}$ & 2 & $98-223$ & $44.90^{\text {a }}$ & 2 \\
$98-105$ & $48.48^{\text {abc }}$ & 3 & $98-68$ & $43.11^{\text {abc }}$ & 3 & $98-278$ & $39.29^{\text {ab }}$ & 3 \\
$98-124$ & $47.26^{\text {abc }}$ & 4 & $98-73$ & $41.96^{\text {abcd }}$ & 4 & $98-220$ & $37.11^{\text {abc }}$ & 4 \\
$98-143$ & $46.46^{\text {abcd }}$ & 5 & $98-58$ & $37.77^{\text {bde }}$ & 5 & $98-154$ & $35.28^{\text {bc }}$ & 5 \\
$98-236$ & $45.88^{\text {abcde }}$ & 6 & $98-44$ & $37.26^{\text {bcde }}$ & 6 & $98-200$ & $34.47^{\text {bcd }}$ & 6 \\
$98-98$ & $44.84^{\text {abcde }}$ & 7 & $98-67$ & $35.83^{\text {bcde }}$ & 7 & $98-30$ & $33.23^{\text {bcde }}$ & 7 \\
$98-207$ & $40.51^{\text {abdef }}$ & 8 & $98-74$ & $34.32^{\text {bcde }}$ & 8 & $98-19$ & $33.01^{\text {bcde }}$ & 8 \\
$98-276$ & $40.29^{\text {abcdef }}$ & 9 & $98-70$ & $33.72^{\text {bcde }}$ & 9 & RC130* & $32.49^{\text {bcde }}$ & 9 \\
$98-11$ & $40.18^{\text {abcdef }}$ & 10 & $98-51$ & $31.63^{\text {bcde }}$ & 10 & $98-196$ & $32.04^{\text {bcdef }}$ & 10 \\
$98-89$ & $39.93^{\text {abcdef }}$ & 11 & $98-54$ & $30.88^{\text {bcde }}$ & 11 & $98-222$ & $30.77^{\text {bcdef }}$ & 11 \\
$98-230$ & $37.83^{\text {abcdefg }}$ & 12 & RL205* & $30.74^{\text {bcde }}$ & 12 & $98-23$ & $30.66^{\text {bcdef }}$ & 12 \\
$98-237$ & $37.72^{\text {bcdefg }}$ & 13 & $98-62$ & $29.84^{\text {bcde }}$ & 13 & $98-257$ & $29.86^{\text {bcdef }}$ & 13 \\
$98-135$ & $37.57^{\text {bcdefg }}$ & 14 & $98-37$ & $28.45^{\text {cde }}$ & 14 & RL205* & $29.3^{\text {bcdef }}$ & 14 \\
$98-84$ & $36.22^{\text {cdefg }}$ & 15 & RC130* & $28.25^{\text {cde }}$ & 15 & $98-18$ & $29.15^{\text {bcdef }}$ & 15 \\
RC130* & $34.86^{\text {cdefg }}$ & 16 & $98-77$ & $27.20^{\text {cde }}$ & 16 & $98-193$ & $27.53^{\text {cdefg }}$ & 16 \\
\hline & & & & & & & & 129
\end{tabular}


Selection based on girth and yield performance of Hevea

\begin{tabular}{|c|c|c|c|c|c|c|c|c|}
\hline \multicolumn{3}{|c|}{ Trial 1} & \multicolumn{3}{|c|}{ Trial 2} & \multicolumn{3}{|c|}{ Trial 3} \\
\hline Clone & $\begin{array}{l}\text { Average } \\
\text { yield }\end{array}$ & Rank & Clone & $\begin{array}{l}\text { Average } \\
\text { yield }\end{array}$ & Rank & Clone & $\begin{array}{l}\text { Average } \\
\text { yield }\end{array}$ & Rank \\
\hline $98-153$ & $32.70^{\text {defg }}$ & 17 & $98-71$ & $26.32^{\mathrm{de}}$ & 17 & $98-15$ & $24.41^{\text {defg }}$ & 17 \\
\hline $98-164$ & $32.11^{\mathrm{defg}}$ & 18 & $98-41$ & $25.56^{\mathrm{de}}$ & 18 & $98-149$ & $23.57^{\mathrm{efg}}$ & 18 \\
\hline $98-201$ & $31.92^{\mathrm{efg}}$ & 19 & 98-07 & $25.48^{\mathrm{de}}$ & 19 & $98-224$ & $23.34^{\mathrm{efg}}$ & 19 \\
\hline RL205* & $29.13^{\mathrm{fg}}$ & 20 & $98-50$ & $24.53^{\mathrm{e}}$ & 20 & $98-26$ & $22.03^{\mathrm{fg}}$ & 20 \\
\hline $98-120$ & $29.05^{\mathrm{fg}}$ & 21 & $98-59$ & $24.48^{\mathrm{e}}$ & 21 & $98-12$ & $21.94^{\mathrm{fg}}$ & 21 \\
\hline $98-83$ & $28.75^{\mathrm{fg}}$ & 22 & $98-55$ & $24.46^{\mathrm{e}}$ & 22 & $98-38$ & $18.88^{\mathrm{g}}$ & 22 \\
\hline $98-25$ & $24.76^{\mathrm{g}}$ & 23 & $98-64$ & $24.23^{\mathrm{e}}$ & 23 & $98-194$ & $18.79^{\mathrm{g}}$ & 23 \\
\hline $98-81$ & $24.54^{\mathrm{g}}$ & 24 & $98-56$ & $24.06^{\mathrm{e}}$ & 24 & & & \\
\hline $98-205$ & $23.44^{\mathrm{g}}$ & 25 & $98-78$ & $23.90^{\mathrm{e}}$ & 25 & & & \\
\hline Mean & 37.65 & & Mean & 31.98 & & Mean & 30.07 & \\
\hline $\begin{array}{l}\text { Root } \\
\text { MSE }\end{array}$ & 9.92 & & $\begin{array}{l}\text { Root } \\
\text { MSE }\end{array}$ & 12.48 & & $\begin{array}{l}\text { Root } \\
\text { MSE }\end{array}$ & 8.81 & \\
\hline $\mathrm{CV}$ & 26.36 & & $\mathrm{CV}$ & 39.04 & & $\mathrm{CV}$ & 29.32 & \\
\hline
\end{tabular}

*Control clones: RRIC 121, RRISL 205, RRIC 130

Means followed by the same letter within a column are not significantly different one another at $\mathrm{p}<0.05$

There were 13 genotypes along with RRIC 121 in all 3 trials, that have shown an average yield higher than $40 \mathrm{~g} / \mathrm{t} / \mathrm{t}$, which was nearly $20 \%$ from the total number of genotypes. RRIC 121 is one of the best performing clones in the country. In this study, it was always ranked at the top level among genotypes in all 3 trials. Thus, 1998 HP progeny consisted of good yielders comparable with RRIC 121, which include potential candidates for the future clonal selection programmes to release high yielding clones for the industry.

\section{Girth performances}

Average girth at the $14^{\text {th }}$ year and average girth increment of immature and post tapping phases were ranked among the tested genotypes from three trials including control clones (Table 2 and Table 3). Average girth at the $14^{\text {th }}$ year after planting in trial 1,2 and 3 ranged from $51.1-80.6 \mathrm{~cm}, 41.3-76.5 \mathrm{~cm}$ and $55.4-71 \mathrm{~cm}$, respectively. Genotypes 98-276 $(80.6 \mathrm{~cm}), 98-68(76.5 \mathrm{~cm})$ and 98-223 $(71 \mathrm{~cm})$ have recorded the highest girth at the final year of evaluation, while these genotypes have represented a mean yield around $40 \mathrm{~g} / \mathrm{t} / \mathrm{t}$. 
P V A Anushka et al.

Table 2. Average girth of genotypes and control clones at the $14^{\text {th }}$ year after planting

\begin{tabular}{|c|c|c|c|c|c|}
\hline \multicolumn{2}{|r|}{ Trial 1} & \multicolumn{2}{|c|}{ Trial 2} & \multicolumn{2}{|c|}{ Trial 3} \\
\hline Clone & $\begin{array}{l}\text { Average girth } \\
\text { (cm) }\end{array}$ & Clone & $\begin{array}{l}\text { Average girth } \\
\text { (cm) }\end{array}$ & Clone & $\begin{array}{l}\text { Average girth } \\
\text { (cm) }\end{array}$ \\
\hline $98-276$ & $80.61^{\mathrm{a}}$ & $98-68$ & $76.50^{\mathrm{a}}$ & $98-223$ & $71.00^{\mathrm{a}}$ \\
\hline $98-230$ & $72.60^{\mathrm{ab}}$ & $98-50$ & $73.11^{\mathrm{ab}}$ & $98-200$ & $66.71^{\mathrm{ab}}$ \\
\hline 98-98 & $72.42^{\mathrm{ab}}$ & $98-80$ & $72.93^{\mathrm{ab}}$ & $98-26$ & $66.00^{\mathrm{ab}}$ \\
\hline $98-219$ & $71.61^{\mathrm{bc}}$ & $98-51$ & $72.19^{\mathrm{abc}}$ & $98-18$ & $63.61^{\mathrm{ab}}$ \\
\hline $98-89$ & $70.06^{\mathrm{bcd}}$ & RL205* & $68.67^{\mathrm{bcd}}$ & $98-38$ & $63.35^{\mathrm{ab}}$ \\
\hline $98-84$ & $69.23^{\text {bcde }}$ & $98-73$ & $67.25^{\text {bcde }}$ & $98-149$ & $63.19^{\mathrm{ab}}$ \\
\hline $\mathrm{RC} 121 *$ & $68.84^{\text {bcde }}$ & $98-58$ & $67.03^{\text {bcde }}$ & $98-193$ & $62.65^{\mathrm{ab}}$ \\
\hline $98-11$ & $68.47^{\text {bcdef }}$ & $98-54$ & $66.50^{\text {bcdef }}$ & $98-15$ & $62.17^{\mathrm{ab}}$ \\
\hline RL205* & $68.30^{\text {bcdef }}$ & $\mathrm{RC} 121 *$ & $66.40^{\text {bcdef }}$ & $98-30$ & $62.08^{\mathrm{ab}}$ \\
\hline $98-207$ & $66.86^{\text {bcdefg }}$ & $98-71$ & $64.73^{\text {cdefg }}$ & $98-278$ & $61.83^{\mathrm{ab}}$ \\
\hline $98-83$ & $66.38^{\text {bcdefg }}$ & $98-64$ & $62.37^{\text {defgh }}$ & $98-154$ & $61.67^{\mathrm{ab}}$ \\
\hline $98-236$ & $66.10^{\text {bcdefg }}$ & $98-44$ & $61.57^{\text {defghi }}$ & $98-220$ & $61.04^{\mathrm{ab}}$ \\
\hline $98-143$ & $63.57^{\text {bcdefgh }}$ & $98-41$ & $61.23^{\mathrm{defghi}}$ & $98-29$ & $61.04^{\mathrm{ab}}$ \\
\hline $98-124$ & $63.06^{\text {bcdefgh }}$ & $98-62$ & $60.29^{\text {efghi }}$ & $98-194$ & $60.92^{\mathrm{ab}}$ \\
\hline $98-153$ & $62.22^{\text {cdefghi }}$ & 98-07 & $59.11^{\text {fghij }}$ & $98-23$ & $60.68^{\mathrm{ab}}$ \\
\hline 98-164 & $62.03^{\text {cdefghij }}$ & $98-77$ & $58.77^{\text {fghij }}$ & RL205* & $60.60^{\mathrm{ab}}$ \\
\hline 98-105 & $60.62^{\text {defghij }}$ & $\mathrm{RC} 130 *$ & $58.29^{\text {ghij }}$ & $\mathrm{RC} 130 *$ & $60.46^{\mathrm{ab}}$ \\
\hline 98-135 & $59.73^{\text {efghijk }}$ & $98-67$ & $57.81^{\text {ghij }}$ & $98-224$ & $59.37^{\mathrm{ab}}$ \\
\hline RC130* & $59.00^{\text {fghijk }}$ & $98-56$ & $57.73^{\text {ghij }}$ & $\mathrm{RC} 121 *$ & $59.05^{\mathrm{ab}}$ \\
\hline $98-25$ & $58.53^{\mathrm{ghijk}}$ & $98-70$ & $56.92^{\text {ghij }}$ & $98-257$ & $58.87^{\mathrm{ab}}$ \\
\hline 98-201 & $56.18^{\text {hijk }}$ & $98-37$ & $55.10^{\mathrm{hijk}}$ & $98-12$ & $58.64^{\mathrm{ab}}$ \\
\hline $98-237$ & $55.00^{\mathrm{hijk}}$ & $98-59$ & $53.75^{\mathrm{ijk}}$ & 98-19 & $58.57^{\mathrm{ab}}$ \\
\hline $98-120$ & $53.00^{\mathrm{ijk}}$ & $98-74$ & $52.25^{\mathrm{jk}}$ & 98-196 & $56.92^{b}$ \\
\hline $98-205$ & $52.67^{\mathrm{jk}}$ & $98-55$ & $48.17^{\mathrm{k}}$ & $98-222$ & $55.44^{\mathrm{b}}$ \\
\hline 98-81 & $51.08^{\mathrm{k}}$ & $98-78$ & $41.28^{1}$ & & \\
\hline Mean & 64.06 & Mean & 61.57 & Mean & 61.61 \\
\hline Root & 10.90 & Root MSE & 9.04 & Root MSE & 13.72 \\
\hline $\mathrm{CV}$ & 17.02 & $\mathrm{CV}$ & 14.68 & $\mathrm{CV}$ & 22.28 \\
\hline
\end{tabular}

*Control clones: RRIC 121, RRISL 205 and RRIC 130

Means followed by the same letter within a column are not significantly different one another at $\mathrm{p}<0.05$ 
Selection based on girth and yield performance of Hevea

Table 3. Average girth increment of genotypes before and after opening for tapping along with the control clones in Trial 1, Trial 2 and Trial 3

\begin{tabular}{|c|c|c|c|c|c|c|c|c|}
\hline \multicolumn{3}{|c|}{ Trial 1 - Girth increment } & \multicolumn{3}{|c|}{ Trial 2 - Girth increment } & \multicolumn{3}{|c|}{ Trial 3 - Girth increment } \\
\hline$\stackrel{\Xi}{0}$ & 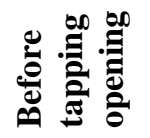 & ¿ & $\frac{\ddot{\Xi}}{0}$ & 哭 & 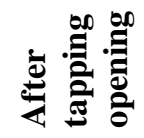 & $\stackrel{\mathscr{\Xi}}{\tilde{U}}$ & 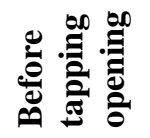 & ¿ \\
\hline $98-276$ & $7.42(1)$ & $1.96(1)$ & $98-68$ & $7.11(1)$ & $1.57(4)$ & $98-223$ & $6.25(2)$ & $2.15(1)$ \\
\hline $98-230$ & $7(2)$ & $1.06(15)$ & $98-50$ & $6.53(6)$ & $2.04(1)$ & $98-200$ & $6.28(1)$ & $1.17(11)$ \\
\hline $98-98$ & $6.93(3)$ & $1.41(7)$ & $98-80$ & $7.04(2)$ & $1.37(7)$ & $98-26$ & $5.89(6)$ & $1.68(2)$ \\
\hline $98-219$ & $6.39(8)$ & $1.70(3)$ & $98-51$ & $6.65(4)$ & $1.65(3)$ & $98-18$ & $5.97(4)$ & $0.98(19)$ \\
\hline 98-89 & $6.26(10)$ & $1.84(2)$ & RL205* & $6.83(3)$ & $1.10(10)$ & $98-38$ & $5.74(11)$ & $1.40(3)$ \\
\hline $98-84$ & $6.73(5)$ & $0.98(17)$ & $98-73$ & $6.15(8)$ & $1.42(6)$ & $98-149$ & $5.77(9)$ & $1.35(4)$ \\
\hline $\mathrm{RC} 121 *$ & $6.68(6)$ & $1.46(6)$ & $98-58$ & $6.58(5)$ & $0.90(14)$ & $98-193$ & $6.02(3)$ & $0.9(21)$ \\
\hline $98-11$ & $6.49(7)$ & $1.24(9)$ & $98-54$ & $5.67(16)$ & $1.91(2)$ & $98-15$ & $5.90(5)$ & $1.03(17)$ \\
\hline RL205* & $6.92(4)$ & $0.91(20)$ & $\mathrm{RC} 121 *$ & $6.52(7)$ & $1.09(11)$ & $98-30$ & 5.69 (14) & $1.19(9)$ \\
\hline $98-207$ & $6.33(9)$ & $1.15(13)$ & $98-71$ & $5.88(12)$ & $1.53(5)$ & $98-278$ & $5.85(7)$ & $0.88(22)$ \\
\hline $98-83$ & $5.78(16)$ & $1.65(4)$ & $98-64$ & $5.73(14)$ & $1.22(8)$ & $98-154$ & $5.72(13)$ & $1.21(7)$ \\
\hline $98-236$ & $5.96(12)$ & $1.56(5)$ & $98-44$ & $6.05(9)$ & $0.82(17)$ & $98-220$ & $5.68(15)$ & $1.15(12)$ \\
\hline
\end{tabular}


P V A Anushka et al.

\begin{tabular}{|c|c|c|c|c|c|c|c|c|}
\hline \multicolumn{3}{|c|}{ Trial 1 - Girth increment } & \multicolumn{3}{|c|}{ Trial 2 - Girth increment } & \multicolumn{3}{|c|}{ Trial 3-Girth increment } \\
\hline$\stackrel{\ddot{\Xi}}{\ddot{\theta}}$ & 我泀 & 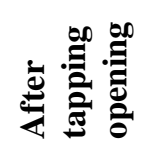 & $\frac{\mathscr{\Xi}}{\tilde{U}}$ & 哭 & 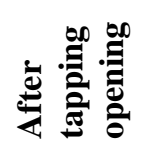 & 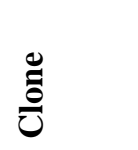 & 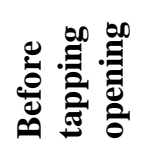 & ¿ \\
\hline $98-143$ & $6.11(11)$ & $0.97(18)$ & $98-41$ & $6.04(10)$ & $0.63(21)$ & $98-29$ & $5.64(16)$ & $1.08(15)$ \\
\hline $98-124$ & $5.92(13)$ & $1.17(12)$ & $98-62$ & $5.8(13)$ & $0.78(20)$ & 98-194 & $5.73(12)$ & $0.99(18)$ \\
\hline $98-153$ & $5.85(15)$ & $1.1(14)$ & $98-07$ & $5.96(11)$ & $0.47(23)$ & $98-23$ & $5.55(18)$ & $1.25(6)$ \\
\hline $98-164$ & $5.92(14)$ & $0.82(22)$ & $98-77$ & $5.7(15)$ & $0.79(19)$ & RL205* & $5.76(10)$ & $0.88(23)$ \\
\hline 98-105 & $5.75(17)$ & $0.95(19)$ & $\mathrm{RC} 130 *$ & $5.44(19)$ & $1.2(9)$ & $\mathrm{RC} 130 *$ & $5.61(17)$ & $1.05(16)$ \\
\hline 98-135 & $5.34(21)$ & $1.29(8)$ & $98-67$ & $5.64(17)$ & $0.86(16)$ & $98-224$ & $5.52(19)$ & $1.18(10)$ \\
\hline $\mathrm{RC} 130 *$ & $5.57(18)$ & $1.21(11)$ & $98-56$ & $5.43(20)$ & $1.02(13)$ & $\mathrm{RC} 121 *$ & $5.83(8)$ & $0.71(24)$ \\
\hline $98-25$ & $5.49(19)$ & $0.88(21)$ & $98-70$ & $5.48(18)$ & $0.8(18)$ & $98-257$ & $5.51(20)$ & $1.15(12)$ \\
\hline 98-201 & $4.95(24)$ & $1.23(10)$ & $98-37$ & 5.09 (23) & $1.08(12)$ & $98-12$ & $5.46(21)$ & $1.20(8)$ \\
\hline $98-237$ & $5.16(22)$ & $0.71(23)$ & $98-59$ & $5.1(22)$ & $0.87(15)$ & $98-19$ & $5.39(22)$ & $1.11(14)$ \\
\hline $98-120$ & $5.36(20)$ & $0.42(25)$ & $98-74$ & $5.12(21)$ & $0.60(22)$ & 98-196 & $5.39(22)$ & $0.90(20)$ \\
\hline 98-205 & $4.97(23)$ & $0.68(24)$ & $98-55$ & $4.66(24)$ & $0.47(24)$ & $98-222$ & $4.93(24)$ & $1.30(5)$ \\
\hline 98-81 & $4.75(25)$ & $1.04(16)$ & $98-78$ & $3.87(25)$ & $0.40(25)$ & & & \\
\hline
\end{tabular}

*Control clones: RRIC 121, RRISL 205, RRIC 130

Means followed by the same letter within a column are not significantly different from one another at $\mathrm{p}<0.05$ 
High yielders did not necessarily associate with high girth increment (Gonçalves et al., 2011), but according to the results, some of the high yielding genotypes such as; 98-219, 98-80, 98-68, and 98-223 have also recorded higher girth values. Forty six genotypes (82\% of genotypes) were comparatively superior to the control clones in terms of girth, while $18 \%$ of genotypes reached above $70 \mathrm{~cm}$, indicating vigorous breeding pool for timber clones.

Average girth increment of the trees provides information on the possibility of the early tappability and vigorous growth. Girth increment of all genotypes has represented a high girth increment at the immature phase compared to post tapping period. It was clear that tapping of the bark has slowed down the growth of the plant. Mean girth increment prior to opening for tapping ranged from 4.8 in genotype $98-81$ to 7.4 in genotype 98 $276,3.9$ in genotype $98-78$ to 7.1 in genotype 98-68 and 4.9 in genotype 98 222 to 6.3 in genotype $98-220$ in Trial 1 , 2 and 3, respectively. Control clone RRIC 121 has recorded the mean girth increments of 6.7 (Trial 1), 6.5 (Trial 2) and 5.8 (Trial 3) before tapping. Around $12 \%$ of the genotypes were at the top ranks achieving an increment of 7 $\mathrm{cm} /$ year the girth before opening for tapping. The mean girth increment during the tapping period has also varied among the genotypes and it was equivalent or less than $2 \mathrm{~cm} /$ year for all genotypes. Genotypes 98-223 (Trial 3), 98-50 (Trial 2) and 98-276 (Trial 1) have recorded higher girth increments. There were five genotypes in Trial 1,10 genotypes in Trial 2 and 23 genotypes in
Trial 3 that have reported higher girth increments when compared to the control clone RRIC 121. Gonçalves et al. (2011) have mentioned that good girthing rate during tapping is a key important factor for a sustainable yield and reduces losses due to wind damage.

\section{Performances of secondary growth parameters}

Recommended minimum girth for opening of tapping is $50 \mathrm{~cm}$ at the height of $120 \mathrm{~cm}$ from the bud union (Onokpise, 1981). At the time of opening, 25 genotypes showed higher percent of tappable trees compared to the control clone RRIC 121. Yet, the control clone RRISL 205 has reported a higher percentage of tappable trees than RRIC 121. Genotypes, 98-230, 98-276, 98-41, 98-50, 98-71, 98-19, 98-196, 98-223 and 98-29 have reported $100 \%$ tappable trees at the time of opening for tapping (Table 4). High percentage of tappable trees ensures a better tapping stand and also reduces the immature phase.

Dead plants were recorded up to the sixth yielding year and survival percentage is given in Table 4. Most probable reasons for the losses are due to wind damages and white root disease. A white root disease patch was identified and the affected plants were uprooted. The incidence of wind damage has caused problems in different forms such as; of branch snap, trunk snap and uprooting (Gonçalves et al., 2007). Severely affected damages were counted as losses. Percentage of survival varied among genotypes. Genotypes; 98-124, 98-25, 98-105, 98-201, 98-41, 98-71, 98-51, 9854, 98-62, 98-44, 98-64, 98-58, 98-56, 
P V A Anushka et al.

98-59, 98-74, 98-78, 98-223, 98-29, 98278, 98-220, 98-12, 98-224, 98-257, 98$18,98-222,98-149,98-15$ and $98-26$ were recorded with $100 \%$ survival. Control clones had better survival percentages. This attribute helps to maintain the proper tapping stand throughout the economic life of the crop and ultimately a good yield.

Incidences of Tapping Panel Dryness (TPD) were also recorded (Table 4) as clonal vulnerability to dryness can be evaluated only after several years of tapping (Gonçalves et al., 2007). Only true cases of dry trees were considered and those became dry due to wind damage have been excluded. Incidence of TPD was observed in almost all the genotypes and control clones except for four genotypes; viz. 98-67, 98-29, 98220 and $98-193$. Genotype 98-84 was the most susceptible genotype which has recorded $80 \%$ of incidence of dryness, followed by 98-236, 98-124 and 98-135 with $73 \%$ incidence of dryness.

\section{Performance of chemical composition in latex}

In order for a comprehensive analysis, chemical properties in latex were also used to identify potential candidate genotypes aiming to reduce the time period taken for the clone development program. Thus, selected eight genotypes and the control clone RRIC 121 were subjected to measurements of chemical composition of selected compounds in latex (Table 5).

Inorganic phosphorus content of latex is directly correlated with the metabolic activity during latex production (Jacob et al., 1989). This attribute ranged from $6.18 \mathrm{mM}$ in genotype $98-124$ to 10.93 $\mathrm{mM}$ in genotype 98-80 among the selected genotypes during high yielding period. When compared to control clone RRIC 121, genotypes 98-80 and 98-219 showed significantly higher yields (Table 1) and also showed significantly higher inorganic phosphorus during both high yielding and wintering periods. Further, genotypes 98-276 and 98-236 showed significantly higher inorganic phosphorus content than the control (Table 5).

Sucrose content ranged from $4.68 \mathrm{mM}$ in genotype $98-219$ to $12.19 \mathrm{mM}$ in genotype 98-236 (Table 5). Sucrose content in latex may signify a good loading to the laticifers (Jacob et al., 1989) which may optimistically affect latex regeneration. On the other hand, genotypes 98-80 and 98-219 have reported higher yields reflecting the high rate of latex regeneration, thereby indicating high amount of sucrose utilization for rubber biosynthesis, resulting lower sucrose level in latex. However, comparatively high level of sucrose content has observed during high yielding period and a low sucrose level in wintering season. This revealed the poor performance in yielding during the wintering season in genotype 98-80 though it has performed well under favorable conditions. High level of sucrose content in genotype 98-236 together with low inorganic phosphorous content reflects its suitability for ethephon stimulation based harvesting systems in future. 
Selection based on girth and yield performance of Hevea

Table 4. Percentage of tappable trees, percentage survival trees and tapping panel dryness (TPD) of Hevea genotypes from the 1998 HP progarmme compared to the control clones in the small scale trials (1,2 and 3) at Kuruwita sub-station

\begin{tabular}{|c|c|c|c|c|c|c|c|c|c|c|c|}
\hline \multicolumn{4}{|c|}{ Trial 1} & \multicolumn{4}{|c|}{ Trial 2} & \multicolumn{4}{|c|}{ Trial 3} \\
\hline$\frac{\mathscr{\theta}}{\tilde{\Xi}}$ & 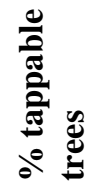 & 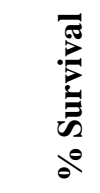 & $\begin{array}{l}\hat{2} \\
\hat{2} \\
0\end{array}$ & 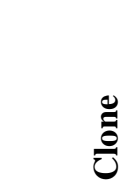 & 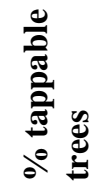 & 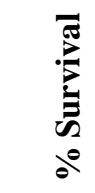 & â & $\frac{\mathscr{\Xi}}{\tilde{\Xi}}$ & 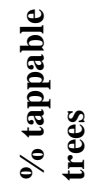 & 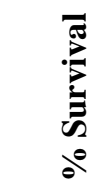 & 20 \\
\hline $98-230$ & 100 & 87.5 & 57.14 & $98-41$ & 100 & 100 & 31.25 & $98-19$ & 100 & 92.86 & 53.85 \\
\hline $98-276$ & 100 & 75 & 33.33 & $98-50$ & 100 & 87.5 & 28.57 & 98-196 & 100 & 92.31 & 9.09 \\
\hline $98-11$ & 93.75 & 93.75 & 53.33 & 98-71 & 100 & 100 & 46.67 & $98-223$ & 100 & 100 & 16.67 \\
\hline $98-84$ & 93.75 & 93.75 & 80 & RL205* & 100 & 93.75 & 13.33 & 98-29 & 100 & 100 & 0 \\
\hline $98-89$ & 93.75 & 75 & 58.33 & $98-51$ & 93.75 & 100 & 50 & RL205* & 100 & 84.62 & 18.18 \\
\hline $\mathrm{RC} 121 *$ & 93.75 & 100 & 25 & $98-54$ & 93.75 & 100 & 18.75 & 98-30 & 92.86 & 92.86 & 38.46 \\
\hline RL205* & 93.75 & 100 & 12.5 & $98-62$ & 93.75 & 100 & 50 & $98-154$ & 91.67 & 92.31 & 30 \\
\hline $98-98$ & 93.33 & 81.25 & 46.15 & $98-68$ & 92.86 & 93.75 & 66.67 & $98-278$ & 91.67 & 100 & 60 \\
\hline $98-219$ & 92.86 & 87.5 & 35.71 & $98-44$ & 87.5 & 100 & 20 & $\mathrm{RC} 121 *$ & 91.67 & 78.57 & 30 \\
\hline $98-143$ & 87.5 & 93.75 & 53.33 & $98-58$ & 87.5 & 100 & 68.75 & $98-220$ & 86.67 & 100 & 0 \\
\hline $98-236$ & 87.5 & 93.75 & 73.33 & $98-64$ & 87.5 & 100 & 37.5 & $98-23$ & 84.61 & 92.31 & 18.18 \\
\hline $98-164$ & 86.67 & 93.75 & 33.33 & $98-73$ & 86.67 & 93.75 & 20 & $98-12$ & 76.9 & 100 & 30.77 \\
\hline $98-124$ & 81.25 & 100 & 73.33 & $98-77$ & 84.61 & 81.25 & 38.46 & $98-193$ & 70 & 92.31 & 0 \\
\hline
\end{tabular}


P V A Anushka et al.

\begin{tabular}{|c|c|c|c|c|c|c|c|c|c|c|c|}
\hline \multicolumn{4}{|c|}{ Trial 1} & \multicolumn{4}{|c|}{ Trial 2} & \multicolumn{4}{|c|}{ Trial 3} \\
\hline$\frac{\ddot{\Xi}}{\tilde{U}}$ & 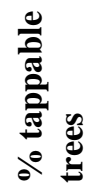 & 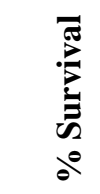 & $\begin{array}{l}\text { 是 } \\
\text { de }\end{array}$ & $\stackrel{\ddot{\Xi}}{0}$ & 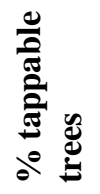 & 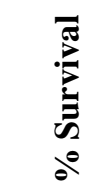 & $\begin{array}{l}2 \\
\text { 20 }\end{array}$ & $\stackrel{巳}{\Xi}$ & 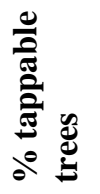 & 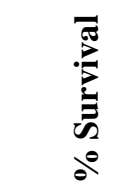 & $\begin{array}{l}\hat{\theta} \\
\hat{\theta} \\
0\end{array}$ \\
\hline 98-207 & 81.25 & 81.25 & 30.77 & 98-07 & 80 & 93.75 & 33.33 & RC130* & 69.23 & 92.86 & 50 \\
\hline $98-25$ & 81.25 & 100 & 33.33 & $\mathrm{RC} 121 *$ & 80 & 93.75 & 7.14 & $98-224$ & 69.2 & 100 & 28.57 \\
\hline $98-83$ & 78.57 & 81.25 & 53.85 & 98-67 & 75 & 75 & 0 & $98-200$ & 66.67 & 76.92 & 22.22 \\
\hline 98-105 & 75 & 100 & 56.25 & $98-56$ & 60 & 100 & 40 & $98-257$ & 66.67 & 100 & 58.33 \\
\hline $98-135$ & 75 & 93.75 & 73.33 & 98-59 & 56.25 & 100 & 31.25 & 98-18 & 64.29 & 100 & 14.29 \\
\hline $\mathrm{RC} 130 *$ & 75 & 87.5 & 71.43 & $\mathrm{RC} 130 *$ & 53.33 & 100 & 57.14 & $98-38$ & 64.29 & 92.86 & 38.46 \\
\hline $98-153$ & 68.75 & 93.75 & 33.33 & 98-70 & 50 & 93.75 & 46.67 & $98-222$ & 54.54 & 100 & 33.33 \\
\hline $98-237$ & 56.25 & 93.75 & 46.67 & $98-74$ & 43.75 & 100 & 37.5 & $98-149$ & 44.44 & 100 & 22.22 \\
\hline 98-201 & 53.33 & 100 & 46.67 & $98-37$ & 26.67 & 93.75 & 33.33 & $98-15$ & 41.67 & 100 & 41.67 \\
\hline $98-120$ & 50 & 75 & 20 & $98-55$ & 26.67 & 93.75 & 14.29 & 98-194 & 33.33 & 93.33 & 21.43 \\
\hline $98-81$ & 46.15 & 75 & 50 & $98-78$ & 12.5 & 100 & 37.5 & $98-26$ & 28.57 & 100 & 28.57 \\
\hline $98-205$ & 37.5 & 87.5 & 28.57 & $98-80$ & 6.25 & 93.75 & 40 & & & & \\
\hline Mean & 79.04 & 89.75 & 15.02 & Mean & 71.13 & 95.5 & 34.72 & Mean & 74.54 & 94.755 & 27.68 \\
\hline SE & 3.55 & 1.76 & 3.67 & SE & 5.8 & 1.28 & 3.44 & SE & 4.53 & 1.38 & 3.53 \\
\hline
\end{tabular}


Selection based on girth and yield performance of Hevea

Table 5. Chemical composition of selected compounds in latex of selected genotypes and the control clone RRIC 121 during high yielding and wintering season

\begin{tabular}{|c|c|c|c|c|c|c|c|c|c|c|}
\hline \multirow[t]{2}{*}{$\begin{array}{l}\text { HP } \\
\text { progeny }\end{array}$} & \multicolumn{2}{|c|}{ Sucrose $(\mathrm{mM})$} & \multicolumn{2}{|c|}{$\begin{array}{c}\text { Inorganic phosphorus } \\
(\mathrm{mM})\end{array}$} & \multicolumn{2}{|c|}{ Thiol (mM) } & \multicolumn{2}{|c|}{ Polyphenol (mM) } & \multicolumn{2}{|c|}{$\begin{array}{c}\text { Dry rubber content } \\
(\%)\end{array}$} \\
\hline & $\begin{array}{l}\text { High } \\
\text { yielding }\end{array}$ & Wintering & $\begin{array}{l}\text { High } \\
\text { yielding }\end{array}$ & Wintering & $\begin{array}{l}\text { High } \\
\text { yielding }\end{array}$ & Wintering & $\begin{array}{l}\text { High } \\
\text { yielding }\end{array}$ & Wintering & $\begin{array}{l}\text { High } \\
\text { yielding }\end{array}$ & Wintering \\
\hline $98-219$ & $4.68^{\mathrm{d}}$ & $1.9^{\mathrm{g}}$ & $10.9^{\mathrm{a}}$ & $0.87^{\mathrm{a}}$ & $0.11^{\mathrm{cd}}$ & $0.24^{\mathrm{a}}$ & $1.35^{\mathrm{d}}$ & $2.08^{\mathrm{a}}$ & $49.04^{\mathrm{e}}$ & $39.28^{\mathrm{c}}$ \\
\hline $98-80$ & $7.53^{\mathrm{b}}$ & $2.61^{\mathrm{f}}$ & $10.93^{\mathrm{a}}$ & $0.92^{\mathrm{a}}$ & $0.18^{\mathrm{bc}}$ & $0.02^{\mathrm{g}}$ & $1.4^{\mathrm{cd}}$ & $1.29^{\mathrm{f}}$ & $48.69^{\mathrm{f}}$ & $40.72^{b}$ \\
\hline 98-105 & $3.74^{\mathrm{e}}$ & $5.35^{\mathrm{b}}$ & $8.29^{\mathrm{d}}$ & $0.48^{\mathrm{bc}}$ & $0.13^{\text {bcd }}$ & $0.02^{\mathrm{h}}$ & $1.13^{\mathrm{e}}$ & $1.56^{\mathrm{d}}$ & $49.92^{\mathrm{d}}$ & $38.68^{\mathrm{c}}$ \\
\hline $98-124$ & $5.19^{d}$ & $2.86^{\mathrm{ef}}$ & $6.18^{\mathrm{e}}$ & $0.53^{\mathrm{b}}$ & $0.11^{\mathrm{cd}}$ & $0.10^{\mathrm{b}}$ & $1.4^{\mathrm{cd}}$ & $1.39^{\mathrm{e}}$ & $50.83^{\mathrm{b}}$ & $44.64^{\mathrm{a}}$ \\
\hline $98-143$ & $6.14^{\mathrm{c}}$ & $3.49^{\mathrm{d}}$ & $10.63^{\mathrm{a}}$ & $0.39^{\mathrm{d}}$ & $0.43^{\mathrm{a}}$ & $0.02^{\mathrm{i}}$ & $1.09^{\mathrm{e}}$ & $1.49^{\mathrm{d}}$ & $54.78^{\mathrm{a}}$ & $34.77^{\mathrm{d}}$ \\
\hline $98-236$ & $12.2^{\mathrm{a}}$ & $4.98^{\mathrm{bc}}$ & $9.2^{\mathrm{c}}$ & $0.41^{\mathrm{cd}}$ & $0.14^{\text {bcd }}$ & $0.03^{f}$ & $1.71^{\mathrm{b}}$ & $1.66^{\mathrm{c}}$ & $50.34^{\mathrm{c}}$ & $38.21^{\mathrm{c}}$ \\
\hline $98-276$ & $6.5^{\mathrm{c}}$ & $4.59^{c}$ & $9.65^{\mathrm{b}}$ & $0.52^{\mathrm{b}}$ & $0.08^{\mathrm{d}}$ & $0.03^{\mathrm{c}}$ & $1.03^{\mathrm{e}}$ & $1.50^{\mathrm{d}}$ & $40.49^{\mathrm{i}}$ & $31.99^{\mathrm{e}}$ \\
\hline $98-68$ & $6.64^{\mathrm{c}}$ & $3.2^{\mathrm{ed}}$ & $6.28^{\mathrm{e}}$ & $0.26^{\mathrm{e}}$ & $0.17^{\mathrm{bc}}$ & $0.03^{\mathrm{d}}$ & $2.65^{\mathrm{a}}$ & $2.07^{\mathrm{a}}$ & $47.97^{\mathrm{g}}$ & $33.71^{\mathrm{d}}$ \\
\hline RRIC 121 & $6.75^{\mathrm{c}}$ & $15.9^{\mathrm{a}}$ & $8.43^{\mathrm{d}}$ & $0.15^{\mathrm{f}}$ & $0.21^{\mathrm{b}}$ & $0.03^{\mathrm{e}}$ & $1.48^{\mathrm{c}}$ & $1.83^{\mathrm{b}}$ & $47.44^{\mathrm{h}}$ & $44.17^{\mathrm{a}}$ \\
\hline Mean & 6.6 & 4.99 & 8.94 & 0.51 & 0.16 & 0.06 & 1.48 & 1.65 & 48.83 & 38.46 \\
\hline $\mathrm{CV}$ & 6.39 & 5.06 & 2.12 & 7.80 & 24.45 & - & 3.57 & 2.92 & - & 1.63 \\
\hline Root MSE & 0.42 & 0.25 & 0.19 & 0.04 & 0.04 & - & 0.05 & 0.05 & - & 0.63 \\
\hline
\end{tabular}


P V A Anushka et al.

Dry rubber content (DRC) during the high yielding period ranged from $47.4 \%$ (RRIC 121) to $54.8 \%$ (98-143). All the selected genotypes showed significantly higher DRC values compared to control clone RRIC 121. Furthermore, genotypes 98-124 and 98-236 also showed high DRC values, $50.8 \%$ and $50.3 \%$, respectively. Though genotypes 98-80 and 98-219 showed comparatively higher DRC, a reduction in DRC was observed in genotype 98-219 during the wintering season and therefore 98-80 would be a better genotype than 98-219 (Table 5).

Thiol content in selected genotypes ranged from $0.08 \mathrm{mM}$ in genotype 98 276 to $0.43 \mathrm{mM}$ in genotype $98-143$ (Table 5). Thiol content in latex has a direct correlation with latex production via acting as a potential activator for key enzymes such as pyruvate kinase and invertase (Jacob et al., 1989). In addition, they act as antioxidants that protect cells against damages caused by reactive oxygen species (De Costa et al., 2006). Genotypes 98-219 and 98-124 showed comparatively higher thiol content even during the wintering season.

High level of phenols could be resulted due to reduced levels of polyphenol oxidase enzyme, which is a key enzyme in latex coagulation (Coupe and Chrestin, 1989). In addition, high level of polyphenol content in latex may cause discoloration in the presence of polyphenol oxidase enzyme (Yapa, 1976). Polyphenol content in selected genotypes ranged from $1.03 \mathrm{mM}$ in genotype $98-276$ to $2.65 \mathrm{mM}$ in genotype 98-68. Genotype 98-68 may produce rubber with high color index due to higher level of polyphenol content. Genotypes 98-219, 98-80, 98-105, 98$124, \quad 98-143$ and 98-276 showed significantly lower level of polyphenol content compared to the control RRIC 121 during the high yielding period (Table 5).

\section{Conclusion}

A proportion of $63 \%$ of new genotypes showed higher mean yield compared to the control clones. Genotypes 98-80 and 98-219 were the top-ranking genotypes that recorded the highest mean yields. When compared to the control clones, $82 \%$ of genotypes have represented higher or comparable mean girth. In terms of girth, $18 \%$ of genotypes showed more than $70 \mathrm{~cm}$ of mean girth and those could be considered as potential genotypes to develop vigorous timber clones in the future. Further, these genotypes showed better yields compared to control clones. Genotypes 98-276, 98-68 and 98-223 recorded respective girth values of $80.6 \mathrm{~cm}, 76.5$ $\mathrm{cm}$ and $71 \mathrm{~cm}$ which were the top most at the final year, based on their girth. With respect to increment in girth, $12 \%$ of the genotypes showed an increment of nearly $7 \mathrm{~cm} /$ year before opening for tapping. Genotypes 98-223, 98-50 and 98-276 have recorded the highest girth increments, viz. $2.2 \mathrm{~cm}, 2.0 \mathrm{~cm}$ and 1.9 $\mathrm{cm}$, respectively after commencement of tapping. In 25 genotypes, higher percent of tappable trees than control, RRIC 121 was observed. According to the chemical properties in latex; genotypes, 98-80 and 98-219 performed well based on DRC, sucrose and inorganic phosphorus. To 
confirm these results, further evaluation of chemical composition in latex should be carried out in a field tapped in virgin panel during the next evaluation stage.

\section{Acknowledgements}

Authors would like to acknowledge the technical support given by the staff of the Genetics and Plant Breeding Department at the Kuruwita sub-station and the staff of the Biochemistry and Physiology Department of the Rubber Research Institute of Sri Lanka.

\section{References}

Anon. (1984). ISO standards Hand Book 22, volume 1 and 2, International Standard Organization.

Attanayake, D P S T G (2001). Clone for commercial planting in Sri Lanka. In: Hand Book of Rubber Vol. 1. Agronomy. pp.46-53. (Eds. L M K Tillekeratne and A Nugawela), Rubber Research Institute of Sri Lanka, Dartonfield, Agalawatta, Sri Lanka.

Boyne, A F and Ellman, G L (1972). A methodology for analysis of tissue sulfhydryl components. Analytical Biochemistry 46, 639-653.

Chandrasekhar, T R, Nice, J, Varghese, Y A, Saraswathyamma, C K and Vijayakumar, K R (2005). Girth growth of rubber (Hevea brasiliensis) trees during the immature phase. Journal of Tropical Forest Science 17 (3), 399-415.

Coupe, M and Chrestin, H (1989). Physicochemical and biochemical mechanisms of hormonal (ethylene) stimulation. In: Physiology of Rubber Latex, (Eds. D'Auzac, J, Jacob, J L and Chrestin, H), CRC Press, Inc., Florida, 345-382.

De Costa, C M, Dos Santos, R C C and Lima, E S (2006). A simple automated procedure for thiol measurement in human serum samples. Brazilian Journal of Pathology and Laboratory Medicine 42(5), 345-350.

Goncalves, P D S, Silva, M D A, Aguiar, A T E, Martins, M A, Junior, E J S and Gouvea, L R L (2007). Performance of new Hevea clones from IAC 400 series. Sci. Agric. (Piracicaba, Brazil). 64(3), 241-248.

Goncalves, P D S, Junior, E J S, Martins, M A, Moreno, R M B, Branco, R B F and Goncalves, E C P (2011). Assessment of growth and yield performance of rubber tree clones of the IAC 500 series. Pesq. agropec. bras. Brasília. 46 (12), 1643 1649.

Jacob, J L, Prevot, J C, Roussel, D, Lacrotte, R, Serres, E, d'Auzac, Eschbach, J M and Omont, H (1989). Yield- limiting factors, latex physiological parameters, latex diagnosis and clonal typology. In: Physiology of Rubber Latex, (Eds. J D'Auzac, J L Jacob and H Chrestin), CRC Press, Inc., Florida, 345-382.

Onokpise, O U (1981). Evaluation of rubber clones (Hevea brasiliensis Mull. Arg) derived from the first hand pollination programme at the Rubber Research Institute of Nigeria. Silvae Genetica 30 (2-3), 37-40.

Reju, M J, Nazeer, M A, Suryakumar, M, Chandrasekhar, T R and Mydin, K K, (2016). Ortet selections from small holdings in Kerala - Long term growth and yield under small scale evaluation in Karnataka. Rubber Science 29 (3), 224237.

Scott, T A and Melvin, E H (1953). Determination of dextran with anthrone. Analytical Chemistry 25(11), 1656-1661.

Taussky, H H and Shorr, E (1953). A micro colourimetric method for the determination of inorganic phosphorous. Journal of Biological Chemistry 202 , 675-685. 
P V A Anushka et al.

Turkmen, N, Sari, F and Sedat Velioglu, Y (2006). Effect of extraction solvents on concentration and antioxidant activity of black and black mate tea polyphenols determined by ferrous tartrate and folinciocalteu methods. Food Chemistry 99, 835-841.

Withanage, S P, Peiris, H P, Kariyawasam, L S, Sarath Kumara, I D M J, Gunasekara, T M S K and Baddewithana, B W A N (2014). Use of yield-yield correlation for early selection of newly developed Hevea genotypes. Journal of the Rubber Research Institute of Sri Lanka 94, 54-68.
Yapa, P A J (1976). Some aspects of phenolic discoloration in natural rubber. Journal of the Rubber Research Institute of Sri Lanka 53, 22-30.

Address for correspondence: Mrs P V A Anushka, Former Research Officer and Dr (Mrs) S P Withanage, Head, Genetics \& Plant Breeding Dept., Rubber Research Institute of Sri Lanka, Nivithigalakele, Matugama, Sri Lanka.

e-mail: anushpva83@gmail.com; pamuditharama@yahoo.com 